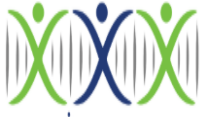

iRASD

Pakistan Journal of Humanities and Social Sciences

Volume 9, Number 3, 2021, Pages 351-355

SCIENCES (P.JSS

Journal Homepage:

https://journals.internationalrasd.org/index.php/pjhss

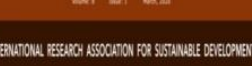

\title{
The impact of Court Fairness on Innovation: Firm-Level Evidence from World Enterprise Survey
}

\author{
Syed Mumtaz Ali Kamzi ${ }^{1}$, Waqar Ahmad ${ }^{2}$, Hira Zulfiqar ${ }^{3}$, Syed Muhammad Imran ${ }^{4}$ \\ ${ }^{1}$ Assistant Professor, Department of Economics, National College of Business Administration and Economics, Pakistan. \\ Email: kazmi.mumtaz@gmail.com \\ 2 M. Phil. Student, Department of Economics, National College of Business Administration and Economics, Pakistan. \\ Email: ahmadwaqar235@gmail.com \\ 3 M. Phil. Student, Department of Economics, National College of Business Administration and Economics, Pakistan. \\ Email: imhira18@gmail.com \\ ${ }^{4}$ Lecturer, Government Associate College Yazman, Pakistan. \\ Email: syedimran.ravian@gmail.com
}

\section{ARTICLE INFO}

\section{Article History:}

Received: October 05, 2021

Revised:

Accepted:

December 01, 2021

December 07, 2021

Available Online: December 08, 2021

\section{Keywords:}

Innovation

Court Fairness

World Enterprise Survey

\section{ABSTRACT}

Innovation works as an engine of growth for the country and the backbone for the performance of the firm. Pakistan is a developing country and it is lagging behind in terms of innovation activities in the region. In Pakistan, due to the weaker quality of institutions, court fairness is biased. The objective of the study was to measure the effect of court fairness on the innovation of the firm in the case of Pakistan using the World Enterprise Survey. The results of the study indicate that court fairness increases the likelihood of innovation. From the perspective of the policy proposal, it is suggested that proper reforms in the judicial system must be initiated and it is the utmost need of the society, firms, and the nation as a whole.

(c) 2021 The Authors, Published by iRASD. This is an Open Access Article under the Creative Common Attribution Non-Commercial 4.0 Corresponding Author's Email: kazmi.mumtaz@gmail.com

\section{Introduction}

Pakistan is a developing country and it is lagging behind in terms of innovation activities in the region. Innovation works as engine of growth for the country and backbone for the performance of the firm. In Pakistan, due to weaker quality of institution, court fairness is biased. According to World Enterprise Survey, 65.04 percent of Pakistani firms reported that the court system is not fair, impartial and uncorrupted (World Enterprise Survey, 2013). The micro-level decision depends upon the quality of institutions, more specifically, on the fairness of court system.

In the last few decades, economists and policy makers have shown much concerned regarding the impact of the institutional quality in improving economic outcomes. Much of the empirical literature focuses on macro-level investigation (Álvarez et al., 2018; Amiri et al., 2019; Belloc, 2006; Chemin, 2009a, 2012; Daude \& Stein, 2007; Do \& Levchenko, 2007, 2009; Eicher \& Leukert, 2009; Francois \& Manchin, 2013; Knack \& Keefer, 1995; P.-G. Méon \& Weill, 2005; P. Méon \& Sekkat, 2008; Mundle et al., 2012; North, 1994; Nunn, 2007; Rodrik et al., 2004). From firms' point of view, institutions reduce uncertainty, minimize cost and increases probability of profit maximization.

The growing empirical work on firm-level focuses on the impact of institutions on exports of the firms (Chakraborty, 2016; Davies \& Jeppesen, 2015; Kapri, 2021; Lin et al., 2020; Melitz, 2003; Olney, 2016; Sheng \& Yang, 2016; Srinivasan \& Archana, 2011; Wang et al., 2014). Specifically, the impact of judiciary on credit market (Jappelli et al., 2005), firm growth (Fisman \& Svensson, 2007), investment (Alesina et al., 2005), contract intensity (Berkowitz et al., 2006; Ma et al., 2010), input tariff (Ahsan, 2013) and it gives firms the comparative advantage (Berkowitz et al., 2006; Do \& Levchenko, 2007; Ranjan \& Lee, 2007). In general, less consideration has been paid to judicial factors. Chemin (2009b) explored the 
relationship between judiciary and entrepreneurship in Pakistan. However, to the best of our knowledge the impact of court fairness on firm-level innovation has not been studied. To fill the gap in the literature, the current study examines the effect of court fairness on firms' innovation activities.

The goal of this paper is to discover the impact of court fairness on different types of firms' innovation activities. For this purpose, the World Bank's Enterprise Surveys data have been used. This paper contributes to the existing literature because to the best of our knowledge, it is the first micro-level study to examine the effect of court fairness on different types of innovation in Pakistan. The paper's structure is as follows. Section 2 discusses existing empirical literature, Section 3 discusses the data and empirical methodology, Section 4 presents the results, and Section 5 concludes.

\section{Literature Review}

Chemin (2009) explored the relationship between judiciary and entrepreneurship in Pakistan. The study utilized the World Enterprise Survey data of Pakistani enterprises to discuss the significance of judicial system for enterprise performance. The difference-indifferences approach was adopted to test the hypothesis of the impact of court fairness on performance of enterprises. The results concluded that judicial system has significant and negative effect of the enterprise performance. Daude and Stein (2007) analyzed the impact of judicial system on development of the firm and its execution in little modern area of Indonesia. For this reason essential information was gathered through poll overview from 55 specialty units of wooden furnishings. Halfway least square strategy was utilized for information investigation. The outcomes show that judicial system has constructive outcome on advancement and firm execution. They propose that judicial quality is necessary for the successful model for business technique and firm execution for little modern area of Indonesia.

Chakraborty (2016) investigated the effect of judicial quality on the performance of the firm. The study utilized the firm level data of Indian enterprises. The study measured the index of institutional and judicial quality through perception based questionnaire. The study employs the firm level micro panel data for different regions of the Indian manufacturing firms. The study further explored the event of criticism joins running from past monetary execution to information and yield phase of development measure. For investigation they look at the consequences of single-condition approach. The results concluded that judicial quality has significant effect on the performance of Indian manufacturing firms. It is therefore proposed that institutional and judicial quality must be improved for the betterment of the firm performance.

Kapri ( 2021) estimated the effect of court fairness on the export of firms using the World Enterprise Data of World Bank. The study employed the instrumental variable Probit model and 2SLS model on South Asian dataset. The quality of institution depends upon the fairness of the court. If the justice system is efficient and fair it will the performance of institution and growth the country. The result of the current study indicates that court fairness is positively associated with tendency to exports. The existing literature investigated the effect of judicial system for various micro and macro level issues. For example, the impact of judiciary on credit market (Jappelli et al., 2005), firm growth (Fisman \& Svensson, 2007), investment (Alesina et al., 2005), contract intensity (Berkowitz et al., 2006; Ma et al., 2010), input tariff (Ahsan, 2013). But the existing literature is lacking in term of the effect of judicial quality on the innovation of the firm. So the recent study tries to fill this gap.

\section{Methodology}

In order to estimate the effect of court fairness on the innovation of the firms we have used following functional relationship.

$$
\text { Innovation }=f(\text { Court Fairness, Human Capital, Foreign Firms, Exports })
$$

For empirical estimation of the model and to measure the effect of court fairness on the innovation of the firms, we have transformed the above functional relationship given in Equation 1 into mathematical model.

$$
I N N O V=\beta_{0}+\beta_{1} C F A I R+\beta_{2} \text { HUCAP }+\beta_{3} \text { FORFIRM }+\beta_{4} \text { EXPORT }
$$


The mathematical model developed in Equation 1 shows the deterministic relationship. But realistically the innovation not only depends on the factors given in Equation 2. In order to get robust results we have included the error term as random variable in Equation 2 to capture the effect of all omitted variable. Thus the econometric model used to get the BLUE estimates is given in Equation 3.

$$
I N N O V=\beta_{0}+\beta_{1} C F A I R+\beta_{2} \text { HUCAP }+\beta_{3} \text { FORFIRM }+\beta_{4} \text { EXPORT }+\mathcal{E}
$$

Where, INNOV is innovation at firm level, CFAIR is court fairness, HUCAP is human capital and EXPORT is the exports of the firm. In this study Innovation is used as dependent variable which is measured by the World Enterprise Survey Question "new product introduced by the firm". The core independent variable is court fairness. It is measured by the World Enterprise Survey Question "Percentage of firms believing the court system is fair, impartial and uncorrupted".

\section{Empirical Results}

The results of the econometric analysis are shown here in this section. The table 1 represents the important summary statistics of the variables. The Table 2 shows the correlation analysis of the variable to estimate effect of court fairness on innovation. The results show that there is positive correlation between the court fairness and innovation of the firm.

Table 1: Summary Statistics

\begin{tabular}{ccccc}
\hline Variables & Mean & Standard Deviation & Minimum & Maximum \\
\hline Innovation & .4236911 & .494175 & 0 & 1 \\
Court Fairness & .1842143 & .3876657 & 0 & 1 \\
Human Capital & .1938889 & .3953485 & 0 & 1 \\
Foreign Firms & 16.59435 & 11.02166 & 0 & 71 \\
Exports & 5.896312 & 19.67124 & 0 & 100 \\
\hline
\end{tabular}

Table 2: Correlation Matrix

\begin{tabular}{cccccc}
\hline & Innovation & Court Fairness & Human Capital & Foreign Firms & Exports \\
\hline Innovation & 1 & & & & \\
Court Fairness & 0.0723 & 1 & & & \\
Human Capital & 0.1096 & 0.0641 & 1 & 1 & \\
Foreign Firms & 0.1165 & 0.1093 & 0.0214 & -0.0443 & 1 \\
$\quad$ Exports & 0.0557 & 0.0144 & 0.0758 & \\
\hline
\end{tabular}

Table 3: The Result of Logistic Regression of the variable to estimate the effect of crime and corruption on capacity utilization

\begin{tabular}{ccccc}
\hline Variables & Coefficient & Standard Errors & Z-Statistics & Probability \\
\hline Court Fairness & 0.3349308 & .1440207 & -2.33 & 0.020 \\
Human Capital & 0.0001902 & .0000541 & 3.52 & 0.000 \\
Foreign Firms & 0.0897147 & .0297454 & 3.02 & 0.003 \\
Exports & 0.3603893 & .0423985 & 8.50 & 0.000 \\
Constant & 0.804738 & .2153599 & 3.74 & 0.000 \\
\hline Pseudo R & \multicolumn{5}{c}{0.0248} \\
Wald chi $^{\mathbf{2}}$ & \multicolumn{5}{c}{41.35} \\
\hline
\end{tabular}

The coefficient of court fairness is 0.3349308 which indicate that if court fairness will increase it will increase the probability of innovation. The results of human capital is 0.0001902 which indicate that human capital will increase the probability of innovation. The existing empirical literature provides strong support to our results. Specifically, the impact of judiciary on credit market (Jappelli et al., 2005), firm growth (Fisman \& Svensson, 2007), investment (Alesina et al., 2005), contract intensity (Berkowitz et al., 2006; Ma et al., 2010), input tariff (Ahsan, 2013) and it gives firms the comparative advantage (Berkowitz et al., 2006; Do \& Levchenko, 2007; Ranjan \& Lee, 2007). The results of logistic regression model show that foreign firms have higher probability of innovation. The results show that exports increases the probability of innovation of the firm. The results of logistic regression model given in Table 3 only show the probability values. In order to measure the unit change in 353 
dependent variable due to change in independent variable we have calculated the marginal effect. The results are given in table 4.

Table 4: The Result of Marginal Effect of the variable to estimate the effect of crime and corruption on capacity utilization

\begin{tabular}{cccc}
\hline Variables & Coefficient & Standard Errors & Probability Value \\
\hline Court Fairness & 0.000055 & .0000802 & -0.069 \\
Human Capital & 0.0004143 & .0007818 & -0.053 \\
Foreign Firms & 0.0263148 & .0276633 & 0.095 \\
Exports & 0.0001328 & .0004335 & -0.031 \\
\hline
\end{tabular}

The coefficient of court fairness is 0.000055 which indicates that keeping all other variable constant, if degree of court fairness increases by 1 percent it will increase the innovation of the firm by 0.005 percent. The coefficient of human capital is 0.0004143 which indicates that if human capital will increase 1 percent it will increase the innovation of the firm by 0.041 percent. The coefficient of foreign firm is 0.0263148 which indicates that if composition of foreign firm in total sample will increase by 1 percent it will increase the innovation of the firm by 2.63 percent. The coefficient of exports is 0.0001328 which indicates that if exports will increase 1 percent it will increase the innovation of the firm by 0.013 percent.

\section{Conclusions and Policy Recommendation}

The objective of the study was to measure the effect of court fairness on the innovation of the firm in the case of Pakistan using the World Enterprise Survey. The results of the study indicate that court fairness increases the likelihood of innovation. The study also concluded that other variables such as human capital, foreign firms and exports of the firms have positive impact on innovation. From the perspective of policy proposal it is suggested that proper reforms in the judicial system must be initiated and it is the utmost need of the society, firms and for the nation as a whole. As our empirical analysis confirm that court fairness improves innovation. So hurdle in degree of court fairness must be removed through proper planning.

\section{References}

Ahsan, R. N. (2013). Input tariffs, speed of contract enforcement, and the productivity of firms in India. Journal of International Economics, 90(1), 181-192.

Alesina, A., Ardagna, S., Nicoletti, G., \& Schiantarelli, F. (2005). Regulation and investment. Journal of the European Economic Association, 3(4), 791-825.

Álvarez, I. C., Barbero, J., Rodríguez-Pose, A., \& Zofío, J. L. (2018). Does institutional quality matter for trade? Institutional conditions in a sectoral trade framework. World Development, 10(3),72-87.

Amiri, H., Samadian, F., Yahoo, M., \& Jamali, S. J. (2019). Natural resource abundance, institutional quality and manufacturing development: evidence from resource-rich countries. Resources Policy, 62(3), 550-560.

Belloc, M. (2006). Institutions and international trade: A reconsideration of comparative advantage. Journal of Economic Surveys, 20(1), 3-26.

Berkowitz, D., Moenius, J., \& Pistor, K. (2006). Trade, law, and product complexity. The Review of Economics and Statistics, 88(2), 363-373.

Chakraborty, P. (2016). Judicial quality and regional firm performance: The case of Indian states. Journal of Comparative Economics, 44(4), 902-918. https://doi.org/https://doi.org/10.1016/j.jce.2016.07.001

Chemin, M. (2009a). Do judiciaries matter for development? Evidence from India. Journal of $\begin{array}{lll}\text { Comparative } \quad \text { Economics, 230-250. } & \text { 23), }\end{array}$ https://doi.org/https://doi.org/10.1016/j.jce.2009.02.001

Chemin, M. (2009b). The impact of the judiciary on entrepreneurship: Evaluation of Pakistan's "Access to Justice Programme." Journal of Public Economics, 93(1), 114-125. https://doi.org/https://doi.org/10.1016/j.jpubeco.2008.05.005

Chemin, M. (2012). Does court speed shape economic activity? Evidence from a court reform in India. The Journal of Law, Economics, \& Organization, 28(3), 460-485.

Daude, C., \& Stein, E. (2007). The quality of institutions and foreign direct investment. Economics \& Politics, 19(3), 317-344.

Davies, R. B., \& Jeppesen, T. (2015). Export mode, firm heterogeneity, and source country 
characteristics. Review of World Economics, 151(2), 169-195.

Do, Q.-T., \& Levchenko, A. A. (2007). Comparative advantage, demand for external finance, and financial development. Journal of Financial Economics, 86(3), 796-834.

Do, Q.-T., \& Levchenko, A. A. (2009). Trade, inequality, and the political economy of institutions. Journal of Economic Theory, 144(4), 1489-1520.

Eicher, T. S., \& Leukert, A. (2009). Institutions and economic performance: Endogeneity and parameter heterogeneity. Journal of Money, Credit and Banking, 41(1), 197-219.

Fisman, R., \& Svensson, J. (2007). Are corruption and taxation really harmful to growth? Firm level evidence. Journal of Development Economics, 83(1), 63-75. https://doi.org/10.1016/J.JDEVECO.2005.09.009

Francois, J., \& Manchin, M. (2013). Institutions, infrastructure, and trade. World Development, 46(2), 165-175.

Jappelli, T., Pagano, M., \& Bianco, M. (2005). Courts and banks: Effects of judicial enforcement on credit markets. Journal of Money, Credit and Banking, 23(2), 223-244.

Kapri, K. (2021). Impact of political instability on firm-level export decisions. International $\begin{array}{llll}\text { Review of E } & \text { Finance, 59(1), }\end{array}$ https://doi.org/https://doi.org/10.1016/j.iref.2018.08.008

Knack, S., \& Keefer, P. (1995). Institutions and economic performance: cross- country tests using alternative institutional measures. Economics \& Politics, 7(3), 207-227.

Lin, J., Flachsbarth, I., \& von Cramon-Taubadel, S. (2020). The role of institutional quality on the performance in the export of coconut products. Agricultural Economics, 51(2), 237258. https://doi.org/https://doi.org/10.1111/agec.12552

Ma, Y., Qu, B., \& Zhang, Y. (2010). Judicial quality, contract intensity and trade: Firm-level evidence from developing and transition countries. Journal of Comparative Economics, $38(2), 146-159$.

Melitz, M. (2003). The impact of trade on aggregate industry productivity and intra-industry reallocations. Econometrica, 71(6), 1695-1725.

Méon, P.-G., \& Weill, L. (2005). Does better governance foster efficiency? An aggregate frontier analysis. Economics of Governance, 6(1), 75-90.

Méon, P., \& Sekkat, K. (2008). Institutional quality and trade: which institutions? Which trade? Economic Inquiry, 46(2), 227-240.

Mundle, S., Chakraborty, P., Chowdhury, S., \& Sikdar, S. (2012). The quality of governance: how have Indian states performed? Economic and Political Weekly, 35(1), 41-52.

North, D. C. (1994). Economic performance through time. The American Economic Review, 84(3), 359-368.

Nunn, N. (2007). Relationship-specificity, incomplete contracts, and the pattern of trade. The Quarterly Journal of Economics, 122(2), 569-600.

Olney, W. W. (2016). Impact of corruption on firm-level export decisions. Economic Inquiry, 54(2), 1105-1127. https://doi.org/https://doi.org/10.1111/ecin.12257

Ranjan, P., \& Lee, J. Y. (2007). Contract enforcement and international trade. Economics \& Politics, 19(2), 191-218.

Rodrik, D., Subramanian, A., \& Trebbi, F. (2004). Institutions rule: the primacy of institutions over geography and integration in economic development. Journal of Economic Growth, $9(2), 131-165$.

Sheng, L., \& Yang, D. T. (2016). Expanding export variety: The role of institutional reforms in developing countries. Journal of Development Economics, 118(1), 45-58.

Srinivasan, T. N., \& Archana, V. (2011). Determinants of export decision of firms. Economic and Political Weekly, 24(1), 49-58.

Wang, Y., Wang, Y., \& Li, K. (2014). Judicial quality, contract intensity and exports: Firm-level evidence. China Economic Review, 31(2), 32-42. https://doi.org/https://doi.org/10.1016/j.chieco.2014.08.002 